\title{
Economic Results in Alfalfa Seed Production
}

\author{
Nemanja Pajić* · Todor Marković
}

University of Novi Sad, Faculty of Agriculture, Trg Dositeja Obradovića 8, 21000 Novi Sad, Serbia

\begin{abstract}
Summary: This paper analyses the most important production and economic results that are achieved in the production of alfalfa seed on family farms in the Republic of Serbia. Alfalfa seed production is characterized by relatively low investment per unit area $\left(499.83 € \mathrm{ha}^{-1}\right)$, but nevertheless, very good economic indicators are achieved in this production (the gross margin $807.00 € \mathrm{ha}^{-1}$; the cost-effectiveness quotient 2.47 ; the profit rate $59.56 \%$ ). The resulting economic parameters represent a good signal for domestic farmers, which in this production can find costeffective alternatives to traditional crops used in crop rotation.

Key words: alfalfa, economics, family farms, production costs, seeds
\end{abstract}

\section{Introduction}

Alfalfa is one of the oldest and the most important fodder crops. It is thought that alfalfa started being cultivated 8,000 years ago in Asia, from where it draws its origins (Ivanov, 1980). During the long history of its cultivation, alfalfa production has been transferred to other continents, where it is still being cultivated. Perennial varieties of alfalfa are very wide-spread all over the world, and depending on the climate the most wide-spread varieties are Medicago sativa $\mathrm{L}$. (common purple alfalfa), Medicago media Pers. (hybrid alfalfa), and Medicago falcata L. (yellow alfalfa) (Lukić, 2000). In the Republic of Serbia, the most wide-spread variety is Medicago sativa $\mathrm{L}$. It is a crop with a life-span is 5 to 7 years, and it can be extended with favourable conditions (Đukić, 1995). Two major ways of exploiting this perennial plant are production of fodder and a combined use of alfalfa in the production of seed and fodder. Agrotechnology used in these two types of exploitation is considerably different (Dragovoz et al., 2002). Alfalfa fodder represents the most important food source for certain categories of cattle. Alfalfa contains around $20 \%$ of raw proteins, and this number depends on the time of haymaking and preparation

\section{Corresponding author:}

nemanjapajic1989@gmail.com

\section{Acknowledgement:}

This study is a part of the project APV 114-451-2180/2016 "Cultivation of forage crops in crop rotation in order to increase soil fertility and biodiversity in agro-ecological conditions of Vojvodina", funded by the Secretariat for Science and Technological Development of AP Vojvodina. It is also a part of the projects III46006 titled "Sustainable agriculture and rural development in order to achieve strategic goals Republic of Serbia in the Danube region".
(Bošnjak \& Stjepanović, 1987). Its proteins have high biological value and their amino-acid content is similar to that of animal proteins (Prentović et al., 1997). These characteristics make alfalfa one of the largest protein producers per unit area. In order to cultivate and exploit alfalfa for seed production, the seeds have to be of high purity and germinability and have to have a high genetic value (Đokić et al., 2011). Most of these demands are met by seed processing, or by removing impurities and seeds of lower quality. Alfalfa seeds are small in size and their separation is possible only with the usage of special equipment (Đukanović et al., 2009). Alfalfa seed production is not very common among domestic farmers and the reason for this is insufficient knowledge on production and economic effects this kind of alfalfa exploitation has. Certain analyses show that this kind of alfalfa exploitation can result in a profit of over $1.000 €$ per unit area, which is a very good result for an arable crop (Samfira et al., 2011).

The aim of this study was to analyse the economic results in the combined use of alfalfa (for production of seed and fodder) in the Republic of Serbia.

\section{Material and Methods}

Basic economic indicators realized in alfalfa seed production on family farms in Serbia were analysed in this work. The study was based on the average calculations of alfalfa seed production in just 5 production years (2010-2014). The data were gathered from five selected farms: Adorjan in Kanjiža Municipality (3.42 ha), Banatsko Karađorđevo in Žitište Municipality (2 ha), Sremski Mihaljevci in Pećinci Municipality (1.14 ha), Grabovac in Obrenovac Municipality (0.86 ha), and Mačkovac in Kruševac 
Municipality (0.29 ha), meaning that all regions of the Republic of Serbia were represented in the calculation. The choice of individual farms was based on the geographic position, or the region a specific farm is situated in. The calculation was primarily based on the calculation of variable costs of production and gross margin as the basic result. In addition, to reliably evaluate the profitability of this production, additional success indicators were calculated (profit, costeffectiveness quotient, and profit rate). What was also taken into account was the fluctuation of the financial result in alfalfa seed production depending on the change in yield and market prices of the product.

This study also shows basic tendencies in the fluctuation of alfalfa fodder production in the Republic of Serbia. The data from the Statistical Office of the Republic of Serbia (www.stat.gov.rs) for the period 2004 -2013 were used for this purpose and processed by means of standard statistical methods.

\section{Results and Discussion}

The decrease in the number of cattle in the last decade was followed by the decrease in land under alfalfa, which was 186,128 ha on average in the analysed period 2004-2013 (Table 1). The mentioned decrease is low in intensity (change rate $-0.85 \%$ ).

There is a considerable variation in the total production of fodder (coefficient of variation 13.34\%) which is due to high oscillations in the achieved yield (coefficient of variation $11.68 \%$ ). Furthermore, there has been a slight decrease in alfalfa yield and fodder production over the last 10 years (Table 1 ).

On the other hand, there is no reliable information on alfalfa seed production in the Republic of Serbia. Namely, in the official statistics there is no data on exploiting alfalfa for its seed. Moreover, one of the problems is the existence of alfalfa seed production which is not agreed upon with the authorized institutes. Therefore, their data cannot be considered as valid. For these reasons, apart from declared alfalfa seed, seeds of questionable quality are also being sold on the market today. This seed material is sold under significantly lower prices compared to those of declared seeds and is usually traded at traditional agricultural meetings, fairs, etc. By eliminating the production of unselected seeds, the quality of production can be increased, the total area and production can be quantified, and this market can finally be regulated. Regulated market and the existence of exact data are the basic conditions that need to be fulfilled in order for the State to regulate and organize alfalfa seed production.

A constant challenge of a modern farmer has to be initiating changes in the sense of decreasing the total costs of production, increasing the value of production per capacity unit, as well as finding the most profitable productions (Ašonja et al., 2008). Answering the question "How profitable is alfalfa seed production in our country?" represents the basic element of this study. For this purpose, the calculation of costs and results of the said production was used (Table 2). In order to analyse the profitability of alfalfa seed production, the total exploitation period of five years (2010-2014) was used in this work, and the costs in the calculation were divided into variable and fixed costs. Variable costs include costs of material (seeds, fertilizer, plan protection products, fuel and lubricants, other materials), costs of labour and direct service, which specifically include the cost of harvesting. Fixed costs include amortisation pertaining to equipment and facilities, as well as bills (taxes and contributions, expenses related to telephone and car usage, etc.). The value of production includes the value of fodder gained in the first year of exploitation (the first, the second, the third cut), that is, the value of seed produced in the second cut and the value of fodder gained from the first and the third cut in other years of exploitation.

Although alfalfa can be sown during two periods, summer and spring, this study analysed farms where sowing took place in the spring period. After the alfalfa field had been set up, in the first year of exploitation all cuts were used for fodder production (Samfira et al., 2011). Production of alfalfa seed should begin in the second year, as the research shows that the highest yield is the result of the second cut (Erić et al., 1995). The analysed farms leave the second cut for alfalfa seed, starting with the second year, and five years after the alfalfa field is set up, alfalfa exploitation seizes. Setting up an alfalfa field requires considerable costs, due to somewhat higher material expenses (668.16 € ha-1).

Table 1. Alfalfa production in the Republic of Serbia (2004-2013)

\begin{tabular}{|c|c|c|c|c|c|}
\hline & \multirow{2}{*}{ Average } & \multirow{2}{*}{$\begin{array}{l}\text { Coefficient of } \\
\text { variation } \\
(\%)\end{array}$} & \multicolumn{2}{|c|}{ Variation interval } & \multirow{2}{*}{$\begin{array}{c}\text { Change rate } \\
(\%)\end{array}$} \\
\hline & & & Minimum & Maximum & \\
\hline Area (ha) & 186,128 & 2.78 & 176,178 & 191,620 & -0.85 \\
\hline Fodder yield $\left(\mathrm{kg} \mathrm{ha}^{-1}\right)$ & 5,416 & 11.68 & 4,032 & 6,003 & -2.55 \\
\hline Fodder production $(\mathrm{t})$ & $1,017,638$ & 13.34 & 734,861 & $1,150,322$ & -1.87 \\
\hline
\end{tabular}


Table 2. Alfalfa production - average calculation (2010-2014)

\begin{tabular}{|c|c|c|c|c|c|c|}
\hline & $1 \mathrm{ha}$ & 2010 & 2011 & 2012 & 2013 & 2014 \\
\hline & Costs & Amount $(€)$ & Amount $(€)$ & Amount $(€)$ & Amount $(€)$ & Amount $(€)$ \\
\hline 1 & Seed & 65.16 & 0.00 & 0.00 & 0.00 & 0.00 \\
\hline 2 & Manure & 364.00 & 0.00 & 0.00 & 0.00 & 0.00 \\
\hline 3 & Fertilizer & 0.00 & 0.00 & 0.00 & 0.00 & 0.00 \\
\hline 4 & Plant protection products & 57.47 & 92.41 & 87.73 & 94.39 & 90.22 \\
\hline 5 & Fuel and grease & 169.06 & 72.80 & 73.92 & 74.48 & 71.12 \\
\hline 6 & Other materials & 12.47 & 9.24 & 9.75 & 10.49 & 10.86 \\
\hline $\mathrm{O}$ & Material costs & 668.16 & 174.45 & 171.40 & 179.36 & 172.20 \\
\hline 7 & Labor costs & 46.80 & 22.50 & 23.90 & 22.70 & 25.60 \\
\hline 8 & Other services (harvesting) & & 146.00 & 162.00 & 160.00 & 170.00 \\
\hline A & Variable costs & 714.96 & 342.95 & 357.30 & 362.06 & 367.80 \\
\hline $\mathrm{B}$ & Fixed costs & 68.34 & 71.97 & 68.12 & 69.26 & 76.41 \\
\hline $\mathrm{C}$ & TOTAL COSTS & 783.30 & 414.92 & 425.42 & 431.32 & 444.21 \\
\hline \multicolumn{7}{|c|}{ Achieved results } \\
\hline 9 & First cut $(\mathrm{kg})$ & 2,875 & 3,284 & 3,841 & 3,257 & 3,342 \\
\hline 10 & First cut $(€)$ & 164.74 & 286.04 & 378.72 & 296.39 & 354.59 \\
\hline 11 & Second cut $(\mathrm{kg})$ & 3,362 & 0 & 0 & 0 & 0 \\
\hline 12 & Second cut $(€)$ & 192.64 & 0.00 & 0.00 & 0.00 & 0.00 \\
\hline 13 & Third cut (kg) & 1,347 & 1,829 & 1,429 & 1,716 & 974 \\
\hline 14 & Third cut $(€)$ & 77.18 & 159.31 & 140.90 & 156.16 & 103.34 \\
\hline 15 & Seed (second cut) (kg) & 0 & 791 & 534 & 593 & 148 \\
\hline 16 & Seed (second cut) $(\boldsymbol{€})$ & 0.00 & $1,431.71$ & 923.82 & $1,168.21$ & 346.32 \\
\hline $\mathrm{D}$ & VALUE OF PRODUCTION & 434.56 & $1,877.05$ & $1,443.44$ & $1,620.75$ & 804.25 \\
\hline $\mathrm{E}$ & GROSS MARGIN (D-A) & -280.40 & $1,534.10$ & $1,086.14$ & $1,258.69$ & 436.45 \\
\hline $\mathrm{F}$ & PROFIT/LOSS (D-C) & -348.74 & $1,462.13$ & $1,018.02$ & $1,189.43$ & 360.04 \\
\hline G & COST-EFFEC. QUOT. (D/C) & 0.55 & 4.52 & 3.39 & 3.76 & 1.81 \\
\hline $\mathrm{H}$ & PROFIT RATE $(\mathrm{F} / \mathrm{D}) * 100$ & & 77.90 & 70.53 & 73.39 & 44.77 \\
\hline
\end{tabular}

High costs are the direct consequence of the necessary usage of manure before this production starts (Bošnjak $\&$ Sikora, 1976). The usage of manure in the analysed individual farms was $364.00 € \mathrm{ha}^{-1}$ on average and it makes up more than $50 \%$ of material expenses in the first year.

In comparison with other production years (in which the second cut is left for seed), higher consumption of fuel and lubricants can be noted in the first year of exploitation, which is the result of higher amount of produced fodder (higher usage of fuel for ploughing, sowing, pressing and transport). On the other hand, the analysed farms do not own harvesters for harvesting seed and therefore pay for this service in the second, third, fourth and fifth year of alfalfa exploitation. Harvesting alfalfa seed is a complex operation and this service costs considerably more than other types of harvesting, for example, harvesting wheat, barley, etc. In all years (in which the second cut was left for seed) this cost included almost half of all the variable costs. As alfalfa is a perennial crop, the costs of seed only exist in the first production year. Another characteristic of alfalfa cultivation is the possibility of not using mineral fertilizer, although the use of fertilizers which contain certain microelements is advisable (B, Mo, Zn) (Lupašku et al., 1985). Mineral fertilizer is not commonly used in the analysed farms and therefore these costs do not exist. The use of plant production products is higher in the years in which the second cut is left for seed. This is due to the use of desiccants a few days before harvesting. Namely, alfalfa flowers on one plant mature unevenly, and it is therefore necessary to desiccate them so as to prevent losses during harvesting (Lukić, 2000).

The value of production is mostly conditioned by the amount of the achieved yield of seed. Natural conditions present during the growth of seed, genetic characteristics, as well as applied agricultural practice are important components for achieving high yields (Martiniello, 1998). In addition, the yield of seed is directly conditioned by the amount of precipitation, as the amount of water directly affects the total amount of the gained seed and 1000 seed 
Table 3. Average results on the analysed farms (2010-2014)

\begin{tabular}{lccc}
\hline Farm & Area (ha) & Cost-effect. quotient & Profit rate \\
\hline Adorjan & 3.42 & 3.04 & 71.28 \\
Banatsko Karađorđevo & 2 & 2.49 & 60.07 \\
Sremski Mihaljevci & 1.14 & 2.73 & 63.49 \\
Grabovac & 0.86 & 1.99 & 51.32 \\
Mačkovac & 0.29 & 2.12 & 53.81 \\
\hline
\end{tabular}

Table 4. Average economic indicators in alfalfa seed production (all farms) $\left(€ \mathrm{ha}^{-1}\right)$

\begin{tabular}{|c|c|c|c|c|c|c|}
\hline & 2010 & 2011 & 2012 & 2013 & 2014 & Average \\
\hline Variable costs & 714.96 & 342.95 & 357.30 & 362.06 & 367.80 & 429.01 \\
\hline Fixed costs & 68.34 & 71.97 & 68.12 & 69.26 & 76.41 & 70.82 \\
\hline Total costs & 783.30 & 414.92 & 425.42 & 431.32 & 444.21 & 499.83 \\
\hline Value of production & 434.56 & $1,877.05$ & $1,443.44$ & $1,620.75$ & 804.25 & $1,236.01$ \\
\hline Gross margin & & & & & & 807.00 \\
\hline Profit/Loss & & & & & & 736.18 \\
\hline Cost-effect. quotient & & & & & & 2.47 \\
\hline Profit rate & & & & & & 59.56 \\
\hline
\end{tabular}

weight (Martiniello, 1998). Only dry farming is present in the analysed farms, and the highest level of production was achieved in the second year of exploitation $\left(1,877.05 € \mathrm{ha}^{-}\right.$ 1), when the yield of seed was the highest $\left(791 \mathrm{~kg} \mathrm{ha}^{-1}\right)$. Deeper analysis shows that the seed yield is better in dry years than in rainy ones. In the third, fourth and fifth production year a considerable amount of production was also recorded. Having in mind the modest investments per unit area, the achieved income can be seen as considerably high. The lowest value of production was recorded in the first year of exploitation (434.56€ ha-1), which is quite logical as no cut was left for seed. As was already mentioned previously, the highest costs are generated in the first production year $\left(783.30 € \mathrm{ha}^{-1}\right)$ which leads to the loss of $348.74 € \mathrm{ha}^{-1}$ in the year of establishing alfalfa field. However, this should be certainly seen as a form of investment, which in other years of exploitation should result in considerable economic success. For these reasons, the profitability of alfalfa seed production is best seen through average economic indicators over five years of exploitation.

Given the average results for the period of five years in alfalfa seed production, there is a very high gross margin for an agricultural production $\left(807.00 € \mathrm{ha}^{-1}\right)$. It is hard to find arable crops which give such a good result per capacity unit, especially because of the fact that this production requires very modest investments per 1 ha. By analysing the profit, similar conclusions can be drawn. Still, gross margin is considered to be a more reliable success indicator than profit, as by using margin indicator the possibility of imprecise division of fixed costs is avoided (Vukoje \& Marković, 2010). By using relative success indicators, reliable evaluation of production profitability can be made (Marković \& Zekić, 2011). Cost-effectiveness quotient obtained by analysing alfalfa seed production is 2.47 and it shows that per $1 €$ of total costs, the value of production of $2.47 €$ is achieved. Profit rate shows that with the analysed crop $59.56 €$ of profit on $100 €$ of the value of production can be achieved. As this is an arable crop, both indicators are very good.

All absolute and relative indicators of success show that alfalfa seed production is very profitable and even more so than most traditional arable crops.

Financial result in agriculture is prone to oscillations in some years due to the fluctuation of yield and prices of final products. Sensitivity analysis shows a high level of tolerance of alfalfa seed production towards the decrease in the total value of production (fodder and seed).

Table 5. Alfalfa sensitivity to changes in the value of production

\begin{tabular}{llllll}
\hline \multirow{2}{*}{ Crop } & \multicolumn{5}{l}{ Fluctuation of profit with the decrease in the value of production $\left(€ \mathrm{ha}^{-1}\right)$} \\
\cline { 2 - 5 } & $-30 \%$ & $-40 \%$ & $-50 \%$ & $-60 \%$ & Realized \\
\hline Alfalfa & 365.38 & 241.78 & 118.18 & -5.43 & 736.18 \\
\hline
\end{tabular}


In the analysed production there is a considerable reserve in the achievement of a positive financial result, given that it achieves a negative value only when the value of production is decreased by $60 \%$.

\section{Conclusion}

Alfalfa represents one of the most important sources of fodder. It is a common source of food for a large number of cattle categories. By combined alfalfa exploitation (for production of seed and fodder), it is possible to considerably improve the economic results per area unit. This study showed that alfalfa seed production provides very high economic parameters (gross margin $807.00 €$ ha $^{-1}$; cost-effectiveness quotient 2.47; profit rate $59.56 \%$ ). Furthermore, this production requires relatively low investments per capacity unit (499.83 $\left.€ \mathrm{ha}^{-1}\right)$. Still, domestic producers' lack of knowledge on production technology of this useful and cost-effective perennial crop is concerning. It is necessary to educate producers through advisory service, producers' union, media, etc., so as to enable farmers to realize the full economic potential of alfalfa production.

\section{References}

Abu-Shakra, S., Akhatar, M., \& Bray, D. W. (1968). Influence of Irrigation Interval and Plant Density on Alfalfa Seed Production. Agronomy Journal, 61(4), 569-571.

Ašonja, A., Sajfert, Z., \& Nikolić, M. (2008). Moderan menadžment u okvirima poljoprivredne i prehrambene proizvodnje. Traktori $i$ pogonske mašine, 13(2), 65-70.

Bošnjak, D., Sikora, I. (1976). Ispitivanje optimalnih sistema obrade i gnojidbe lucerke na smeđem tlu i pseudogleju. Zbornik radova (1739). Osijek: Poljoprivredni Institut.
Bošnjak, D., Stjepanović, M. (1987). Lucerka. Sarajevo: NIRO Zadrugar.

Dragovoz, I. V., Kots, S. Y., Chekhun, T. I., Yavorskaya, V. K., \& Volkogon, N. V. (2011). Complex Growth Regulator Increases Alfalfa Seed Production. Russian Journal of Plant Physiology, 49(6), 823-827.

Đokić, D., Stanisavljević, R., Terzić, D., Marković, J., Štrbanović, R., Mileusnić, Z., \& Dimitrijević, A. (2011). Dorada semena lucerke na različitim sistemima mašina. Journal on Processing and Energy in Agriculture, 15(3), 201-204.

Đukanović, L., Filipović, Đ., Glumac, I., \& Dević, A. (2009). Efekat različitih faza dorade na čistoću semena lucerke. Casopis za procesnu tehniku i energetiku u poljoprivredi, 13(3), 268-270.

Đukić, D. (1995). Opšti deo i oplemenjivanje lucerke (pp. 1-41). In: D. Đukić, P. Erić (Eds). Lucerka. Novi Sad: University of Novi Sad, Faculty of Agriculture.

Erić, P., Ćupina, B., Mihailović, V., \& Trifunović, T. (1995). Uticaj otkosa na prinos i kvalitet semena. Zbornik radova Instituta za ratarstvo i pourtarstvo, Novi Sad, 23, 461-471.

Ivanov, A. I. (1980). Lucerna. Moskva: Kolos.

Karagić, Đ., Katić, S., Mihailović, V., Erić, P., \& Milić, D. (2006). Proizvodnja semena lucerke u Vojvodini. Zbornik radova Naúnog instituta za ratarstvo i povrtarstvo, Novi Sad, 42, 115-130.

Lukić, D. (2000). Površine i rasprostranjenost najvažnijih vrsta lucerke (pp. 9-14). In: D. Lukić (Ed). Lucerka. Novi Sad: Naučni institut za ratarstvo i povrtarstvo.

Lupašku, F. M., Lala, M., Bolokan, N. I., \& Zabrijan, D. P. (1985). Programirovanie urožaev lucerni. Vestnik s. h. nauki, 6, 94-101.

Marković, T., Zekić, V. (2011). Ekonomske karakteristike proizvodnje šećerne repe. Ratarstvo i Povrtarstvo, 48(2), 423-428.

Martiniello, P. (1998). Influence of agronomic factors on the relationship between forage production and seed yield in perennial forage grasses and legumes in a Mediterranean environment. Agronomie, 18, 591-601.

Prentović, T., Ivanovski, R. P., \& Dimov, Z. (1997). Kvalitetna svojstva sorti lucerke kao osnova za dalji selekcioni rad. Selekcija $i$ semenarstvo, 4(3-4), 157-160.

Samfira, I., Moisuc, A., Sarateanu, Veronica, Gaitin, D., \& Motiu, D. (2011). Yield Capacity and Production Costs in NS Banat ZMS II Alfalfa Variety Cultivated in Siria, Arad County. Journal of Agricultural Science, 43(1), 261-265.

Vukoje, V., Marković, T. (2010). Analiza ekonomskih efekata proizvodnje vodećih ratarskih useva na porodičnim gazdinstvima. Savremena poljopriveda, 59(1-2), 15-21.

\section{Ekonomski rezultati u proizvodnji semena lucerke}

\section{Nemanja Pajić · Todor Marković}

Sažetak: U radu se analiziraju najvažniji proizvodni i ekonomski rezultati koji se ostvaruju u prozvodnji semena lucerke na porodičnim poljoprivrednim gazdinstvima u R. Srbiji. Proizvodnju semena lucerke karakterišu relativno niska ulaganja po jedinici površine (499,83€ ha-1), ali uprkos tome, u ovoj proizvodnji ostvaruju se vrlo dobri ekonomski pokazatelji (marža pokrića 807,00 € ha-1; koeficijent ekonomičnosti 2,47; stopa dobiti 59,56\%). Dobijeni ekonomski parametri predstavljaju dobar signal domaćim poljoprivrednicima, koji u ovoj proizvodnji mogu pronaći isplativu alternativu tradicionalno prisutnim usevima u plodoredu.

Ključne reči: ekonomija, lucerka, porodična poljoprivredna gazdinstva, seme, troškovi proizvodnje 